\title{
Study on the prevalence of Foot and Mouth Disease in Borana and Guji Zones, Southern Ethiopia
}

\author{
Habtamu Mekonen, ${ }^{1}$ Desta Beyene ${ }^{1}$, Tesfaye Rufael ${ }^{2}$, Ashenafi Feyisa ${ }^{3}$ and Fufa, Abunna ${ }^{4 *}$ \\ ${ }^{1}$ Haramaya University, Faculty of Veterinary Medicine, P.O.Box, 138, Dire Dawa, Ethiopia \\ ${ }^{2}$ National Animal Health Diagnostic and Investigation Center, P.O.Box 4, Sebeta, Ethiopia \\ ${ }^{3}$ Addis Ababa University, Faculty of Veterinary Medicine, Debre Zeit, P.O.Box 34, Ethiopia \\ ${ }^{4}$ Hawassa University, Department of Veterinary Medicine, P.O.Box, 05, Hawassa, Ethiopia \\ * Corresponding author email : drfufex@yahoo.com \\ Published Online : 30-04-2011
}

\begin{abstract}
A cross sectional study was conducted on Borana plateau and Guji highlands of southern Ethiopia to determine the prevalence of Foot and Mouth Disease (FMD) in bovine species. Seroprevalence investigation was performed using 3ABC- ELISA technique. The result indicated that the overall prevalence of Foot and Mouth Disease was $24.6 \%$ (113/460). Significantly higher prevalence was recorded in Borana 53.6\%( 82/153) compared to Guji 10.1\%(31/307). From the various risk factors, geographical distribution $\left(\chi^{2}=104.26, P<0.05\right)$ and age $\left(\chi^{2}=6.68, P<0.05\right)$ were seen to be significantly associated with the seroprevalence. The result of this study indicated that FMD is highly prevalent in lowland area (Borana) than highland (Guji) due to contact of different origin cattle in search of feed and water. The presence of higher prevalence of Foot and Mouth Disease in pastoralists' cattle of the area warrants further investigation and characterization of the circulating virus serotype to apply effective control and prevention measures.
\end{abstract} Key words: Seroprevalence, FMD, Borana, Guji, 3ABC ELISA, Ethiopia

\section{Introduction}

Foot and mouth Disease, which is also known as aphtous fever (Kahrs, 2001), is a major global animal health problem (Murphy et al., 1999). It is the most contagious trans-boundary animal disease (TAD) affecting cloven hoofed animals (FAO, 2007) characterized by the formation of vesicles in the mouth, at coronary band and skin of interdigital cleft (Radostits et al., 2000).

Of the seven Foot and Mouth Disease Virus serotypes, $\mathrm{O}$ is the most worldwide encountered (Reid et al, 2002). Serotypes A \&O, have the widest distribution, occurring in Africa, Asia and South America. Types SAT1, 2 and 3 are currently restricted to Africa only and Asial to Asia (FAO, 2007).

According to the office international des epizootics (OIE), FMD ranks first among the notifiable infectious diseases of animals (OIE, 2000). The disease is notoriously contagious that it can spread as much as 50(fifty) miles down wind from one outbreak area to another (Sainsbury, 2000). Introduction of the virus types or subtypes to regions where they were previously absent lead to epidemics of varying magnitude (Gibbs, 1981). When the disease breaks out in susceptible cattle, it spreads very rapidly and the morbidity rates approximate 100\%. The disease is rarely fatal except in young animals (Kahn and Scottline, 2005).

FMD has a great potential for causing severe economic loss in susceptible cloven-hoofed animals (OIE, 2000). Greater losses can result from refusal of FMD free countries to import livestock and livestock products from infected regions (Kahrs, 2001) Adult mortality is not very high but causes heavy economic losses (loss of flesh, diminished milk production, mastitis, calf mortality etc). This combined with the time and money spent treating animals and their long convalescence contributes to consider it the single most important animal disease in a worldwide contest (Solomon, 1980).

There is no reliable figure for the prevalence of FMD in different countries. The disease generally occurs in the form of an outbreak that rapidly spread from herd to herd before it is controlled (Radostits et al., 2000). The disease is endemic in Ethiopia, the main incidence being after the rainy season when cattle are subjected to the stress of harvesting and thrashing (Solomon, 1980). The occurrence of FMD in Ethiopia is increasing and in 1999 almost $10 \%$ of cattle were under risk of infection and in 2000 and 2001 a total of 27 and 88 disease outbreaks were reported 
(Esayas et al., 2005).

The most important resource in the prevention of FMD is the informed animal owner or manager. Livestock owners at all levels of production, dealers and traders should be familiarized with the basic features of FMD, including the recognition of the essential signs of the disease, the need for urgent action and how and where to seek help if they suspect the disease (FAO, 2002). Therefore, the objective of this study is to determine the prevalence of the disease in two different geographical areas of Oromiya region, Southern Ethiopia.

\section{Materials and Methods}

Study Area: The study was conducted from November 2007 to March 2008 on serum samples, which were collected from cattle of Borana and Guji zones, Southern Ethiopia.

The Borana, zone of pastoral system, covers a vast lowland area in southern Ethiopia covering about $95,000 \mathrm{Km}^{2}$, which is located $567 \mathrm{Km}$ from Addis Ababa between $03^{\circ} 37^{\prime} 23.8^{\prime \prime}$ to $05^{\circ} 02^{\prime} 52.4^{\prime \prime}$ North and $37^{\circ} 56^{\prime} 49.4^{\prime \prime}$ to $39^{\circ} 01^{\prime} 101^{\prime \prime}$ East, in the Southern part of Ethiopia. The altitude ranges from 970 masl in the south bordering Kenya to 1693 masl in the North east. The area receives mean annual rainfall of $600 \mathrm{~mm}^{3}$ with mean minimum and maximum annual temperatures of $19^{\circ} \mathrm{c}$ and $24^{\circ} \mathrm{c}$ respectively (Coppock, 1994). The Borana zone is dominated by savannah vegetation containing mixture of perennial and woody bush land. The major water sources are ponds and deep wells during rainy and dry periods respectively (Helland, 1997). Different ethnic groups inhabit the Borana zone. The most significant inhabitants belong to the various Oromo and Somali clans. Among the Oromo clans, the Guji Oromo settled in humid lands at higher altitude. Guji is also study area, which is a highland of southern Ethiopia borders with Borana.

Study Population: Study animals were selected from Borana pastoral cattle population in 6 districts of namely: Bule Hora, Moyale, Abaya, Yabello, Galana and Dire and from Guji Zone cattle in 10 districts namely: Bore, Adola, Wadara, Odo shakisa, Odoshakiso, Liben, Uraga, Uraga dama, Kercha and Hanbela, from which 153 and 307 animals are selected respectively. Approximately 14 animals from each PAs were selected randomly to be included in the study. Accordingly, 33PAs and 460 animals were included in the study. The study animals were not vaccinated for FMD.

Sample size determination: The sample size was estimated by assuming a prevalence of $50 \%$ to get the maximum number required to determine the prevalence in simple random sampling. The precision was decided to be $5 \%$ at $95 \%$ confidence level. Thus, for sample size estimation the formula described by Thrush field, 1995 was used.

Accordingly, the minimum sample size required was 384, but 460 cattle from Borana and Guji areas were considered in the study of prevalence of FMD.

\section{Study Design}

Cross sectional study: A cross sectional study was undertaken from November 2007 to March 2008. During the laboratory work, a total of 460 sera samples collected from herds of Borana and Guji cattle were examined by using $3 \mathrm{ABC}$ ELISA for the detection of FMD antibodies.

Sample collection: Blood samples were collected from jugular vein of individual animals using $10 \mathrm{ml}$ sterile vaccutainer tubes. The owner(s) handled the animals properly. After taking the sample code was given to the tubes, which contain the sample. Then the blood was allowed to clot by placing it overnight at room temperature. The serum was collected from the clotted blood and transported using an icebox to National Animal Health Diagnostic and Investigation Center (NAHDIC), Sebeta, then transferred into a single sterile cryovials and labeled with specific laboratory number. The sera sample then stored at $20^{\circ} \mathrm{c}$ until laboratory investigation.

Laboratory Test: The SVANOVIR $®$ Foot and Mouth Disease Virus 3ABC-Ab ELISA kit was designed to detect FMDV specific antibodies in bovine serum samples. The kit procedure was based on a solid phase indirect ELISA. In this procedure, samples were exposed to non-infectious FMDV antigen (NSP $3 A B C)$ coated wells on micro titer plates. FMDV antibodies (if present in the test sample) bind to the antigen in the well. HRP conjugate added subsequently forms a complex with the FMDV antibodies. Unbound materials removed by rinsing before the addition of substrate solution. Subsequently a blue-green color develops which is due to the conversion of the substrate by the conjugate. The reaction stopped by the addition of stop solution. The result can be read by a micro plate photometer, where the optical density (OD) measured at $405 \mathrm{~nm}$.

Data analysis: The data collected was entered into M- Excel and coded for analysis. The laboratory investigation for prevalence results were analyzed using statistical package for Intercooled STATA 7.1. Variation of the prevalence between the two different geographical areas, Borana and Guji, was analyzed by using chi-square $\left(\chi^{2}\right)$ test. In all the analysis, confidence 
Study on the prevalence of Foot and Mouth Disease in Borana and Guji Zones, Southern Ethiopia

Table-1: Seroprevalence of FMD in cattle of different origin

\begin{tabular}{lllllc}
\hline Origin & \multicolumn{2}{c}{ No of samples } & \multicolumn{2}{c}{ Serological status } & \multicolumn{2}{c}{$\begin{array}{c}\text { Prevalence } \\
\text { (\%) }\end{array}$} \\
\hline Borana & $\mathrm{n}$ & $\%$ & $-\mathrm{ve}$ & 82 & 53.6 \\
Guji & 153 & 33.26 & 71 & 31 & 10.1 \\
Total & 307 & 66.74 & 276 & 113 & 24.6 \\
\hline
\end{tabular}

Table-2: Sroprevalence of FMD in different sex groups

$\left(\chi^{2}=104.3, P<0.05\right)$

\begin{tabular}{|c|c|c|c|c|}
\hline \multirow[t]{2}{*}{ Sex } & \multicolumn{2}{|c|}{ No of samples } & \multirow{2}{*}{$\begin{array}{c}\text { Positive } \\
\text {-ve }\end{array}$} & \multirow{2}{*}{$\begin{array}{c}\text { Prevalence } \\
\text { (\%) }\end{array}$} \\
\hline & $\mathrm{n}$ & $\%$ & & \\
\hline $\begin{array}{l}\text { Male } \\
\text { Female } \\
\text { Total }\end{array}$ & $\begin{array}{l}152 \\
308 \\
460\end{array}$ & $\begin{array}{l}33.04 \\
66.96 \\
100\end{array}$ & $\begin{array}{c}29 \\
84 \\
113\end{array}$ & $\begin{array}{c}19.1 \\
27.3 \\
53.59\end{array}$ \\
\hline
\end{tabular}

Table-3: Sroprevalence of FMD in different sex groups

$\left.\chi^{2}=3.69: P>0.05\right)$

\begin{tabular}{lllcc}
\hline Age & \multicolumn{2}{c}{ No of samples } & Positive & Prevalence \\
-ve & (\%) & 16.8 \\
\hline Heifer & 101 & 21.96 & 17 & 0.10 \\
Bull & 18 & 3.91 & 2 & 27.6 \\
Adult & 341 & 74.13 & 94 & 53.59 \\
Total & 460 & 100.00 & 113 & \\
\hline
\end{tabular}

level was at $95 \%$ and $\mathrm{P}<0.05$ set for significance.

\section{Result}

During the study period 460 serum samples were examined for the presence of antibody against FMD virus using Non Specific Protein (NSP) 3ABC ELISA test. The samples were Borana $(n=153)$ and Guji $(n=307)$.

From 460 serum samples examined for the presence of antibody to the $3 \mathrm{ABC}$ nonstructural protein of FMD virus, $24.57 \%$ (113/460) indicate positive result. The highest prevalence recorded in Borana $53.59 \%(82 / 153)$ was significantly different $\left(\chi^{2}=104.3, \mathrm{P}<0.05\right)$ from the prevalence recorded in Guji 10.1\%(31/307) (Table 1).

On the other hand, higher disease prevalence $27.3 \%(84 / 308)$ was observed in females than the prevalence of males $19.1 \%(29 / 152)$ (Table 2). The difference in prevalence of FMD between the two sex groups was found to be statistically not significant $\left(\chi^{2}\right.$ $=3.69: \mathrm{P}>0.05)($ Table 3$)$.

Age specific seroprevalence study revealed a higher prevalence in adult $27.6 \%$ (94/341) followed by heifer $16.8 \%(17 / 101)$ and bull $0.1 \%(2 / 18)$. The difference among prevalence in age status was found to be statistically significant $\left(\chi^{2}=6.67, \mathrm{P}<0.05\right)$ (table 3$)$.

\section{Discussion}

Currently Ethiopia exports beef animals to
Egypt, most of which originate from Borana pastoral areas. Foot and Mouth Disease is one of the most diseases that can cause restriction on the trade of animals both locally and internationally, thereby threatening the livelihood of Borana pastoralists in particular and national agricultural economy in general (Rufael, 2006).

The overall seroprevalence rate of $24.6 \%$ reported in this study was in agreement with the previous finding from Ethiopia (Sahle, 2004) in which seropositivity of $26.5 \%$ was reported. The prevalence of FMD in samples of Borana origin was $53.6 \%$ ( $82 / 153$ ) which is greater than (Rufael, 2006) which reported $21 \%$ in Borana pastoral system. The increase in prevalence from the previous study may be may be associated with extensive movement of livestock and the high rate of contact between animals at marketing and common grazing places as well as at watering points (Mersie, et al., 1992).

Significant difference found between areas of different altitude with a prevalence of $53.6 \%$ and $10.1 \%$ at low and high altitude, respectively. This variation may be due to the fact that in lowland areas (Borana) cattle have to move long distance in search of good pasture and surface water (Rufael, 2006) lead to contact of cattle of different origin, which is the predominant factor for the transmission of the disease. The reason for the rapidity of spread to fully susceptible population is due to the highly infectious le 
nature of the virus, the production of high titer in respiratory secretions and the large volumes of droplets and aerosol of virus shed by infected animals, the stability of virus in such droplets, the rapid replication cycle with very high virus yields and the short incubation period (Sellers and Daggupaty, 1990).

Significant difference was observed between different age groups $\left(\chi^{2}=6.68, P<0.05\right)$. The relatively low seroprevalence in younger animals may be indicative of low frequency of exposure to risk factors. Therefore, adult animals might have acquired the infection from multiple serotypes and could produce antibodies against all serotypes of FMD.

The correlation of the disease can be explained by the contagious nature of the disease and mode of transmission, which is enhanced by crowding and frequency of contact. Although sex is appeared to have a significant effect on seropositivity in univariate analysis (Table-2), it was found not to have a significant effect $\left(\chi^{2}=3.69, \mathrm{P}>0.005\right)$.

In Ethiopia outbreak of FMD frequently occurs in the pastoral herds of the marginal lowland areas of the country (Sahle et al., 2004). This is mainly due to the lack of effective vaccine, absence of livestock movement control and absence of systematic disease surveillance and reliable epidemiological data. It is however likely that the disease is underreported due to comparatively high tolerance of local breeds to the clinical episodes of the disease. It seems therefore that FMD is more prevalent and has been one of the major causes for considerable economic loss of the rural communities in Ethiopia.

In endemic countries (like Ethiopia), vaccination is the best control strategy that may be applied with quarantine. Vaccines must be formulated taking into account the virus type and subtypes prevalent in the area and vaccination programmes must cover not less than $80 \%$ of the susceptible population, preferably $100 \%$ of cattle so as to maintain a reliable hard immunity status (OIE, 2000).

In conclusion, the study has proven that Foot and Mouth Disease is highly contagious and a serious impediment for cattle production. The disease is highly prevalent in animals that experience uncontrolled movement through regions and international boundaries.

\section{Acknowledgements}

The study was supported by Hawassa University and National Animal Health Diagnostic and Investigation Centre (NAHDIC) which deserved enormous appreciation from the authors. The willingness and cooperation of flock owners were indispensable inputs for the accomplishment of this study. All contributions and supports are gratefully acknowledged.

\section{References}

1. Desta S. (1999). Diversification of livestock assets for risk management in the Borana pastoral system of Southern Ethiopia, PhD thesis Utah State University, Logan, Utah. Pp10-31: Cited in; Rufael T. (2006). Participatory appraisal and seroprevalence study of Foot and Mouth Disease in Borana pastoral system, Southern Ethiopia, MSc thesis FVM, AAU, Debre zeit, Ethiopia. Pp 1-89.

2. Esayas G., Berhanu B., Gelagay A. (2005). Foot and Mouth Disease serotypes identified in Ethiopia. Ethiopian Veterinary Association Journal. 9(1): Pp 75-77.

3. FAO, (2002). Preparation of Foot and Mouth Disease Contingency Plans. FAO animal health manual 16: Pp 2160 .

4. FAO EMPRES and EUFMD commission (2007). Foot and Mouth Disease distribution worldwide and major epidemiological events in 2005-2006. Contributors; Sumption K., Dinto J., Lubroth J., Morzaria S.,Murray T., DeLa Rocque S., Njeumi F., No 1: Pp 1-9.

5. Kahrs, F.R. (2001). Foot and Mouth Disease In: Viral diseases of cattles. IOWA state university press Pp 271-275.

6. Kahn, C. M. and Scottline, (2005). Foot and Mouth Disease In: The Merck Veterinary Manual. $9^{\text {th }}$ Edition. Merck and Co. Inc. Whitehouse Station. NJ USA. Pp509-511.

7. Mersie, A., Tafesse, B., Getahun, F. and Teklu, W. (1992). Losses from Foot and Mouth Disease in a mixed farming area of eastern Ethiopia. Tropical Animal Health and Production, 24(3): Pp 144-152.

8. Murphy, A.F., Gibbs, J.E., Horzinec, C.M. and Studdert, J.M. (1999). Foot and Mouth Disease In: Veterinary Virology. $3^{\text {rd }}$ edition California, Acadamic press USA. Pp 512-537.

9. OIE, (2000). World organization for animal health. Manual of standards for diagnostic tests and Vaccines. Office International desEpizootics Paris. Pp 77-86.

10. Radostits, O.M., Gay, C.C., Blood, D.C. and Hinchcliff, K.W. (2000). Veterinary Medicine. A textbook of the diseases of cattle, sheep, pigs, goats and horses. Foot and Mouth Disease, $9^{\text {th }}$ edition China, Elsevier LTD Pp 10591064.

11. Rufael T. (2006). Participatory appraisal and seroprevalence study of Foot and Mouth Disease in Borana pastoral system, Southern Ethiopia, MSc thesis FVM, AAU, Debre zeit, Ethiopia Pp 1-89.

12. Sahle, M., Dwarka R.M., Venler E.H., Volsoo W. (2004). Molecular epidemiology of serotype O Foot and Mouth Disease Viruses isolated from cattle in Ethiopia between 1979-2001. Onderstepoort Journal of Veterinary Research 71: Pp129-138.

13. Sellers, R.F. and Daggupaty, S.M. (1990). The epidemiology of Foot and Mouth Disease in Saskatchewan, Canada, 19511952 C anadian Journal of Veterinary Research. 54: Pp 457. 464.

14. Solomon, H. (1980). Animal health review Ethiopia 19721979. Ministry of agricultural Livestock research development department veterinary service division $\mathrm{Pp} 275$ 276.

$* * * * * * * *$ 